\title{
PENGATURAN PARKIR KENDARAAN MASUK/KELUAR AREA PARKIR DAN MEMBANTU PENGEMUDI SAAT PARKIR BERBASIS MIKROKONTROLLER
}

Oleh :

\section{Laxsmy Devy}

Staf Pengajar Teknik Elektro Politeknik Negeri Padang

\begin{abstract}
Many parking area still use manual system such as ticketing, parking position, etc. Nowadays, this system can be control easier using microcontroller. In this control system, infra red and photodiode are used to inform when car come and out to parking area. Another sensor, ultrasonic, is used to help driver to park the car safely. Alarm will warn the driver if the position of the car broke the limitation of safety range to park. In another hand, the empty parking areas are display in LCD and related with portal which opened when the empty parking area still available and close if it full automatically. Microcontroller is used to control sensor, LCD and portal.
\end{abstract}

Keyword: parking area, microcontroller, sensor, $L C D$

\section{PENDAHULUAN}

\begin{tabular}{llr}
\multicolumn{2}{c}{ Meningkatnya } & kemampuan \\
masyarakat di perkotaan untuk \\
memenuhi fasilitas transportas
\end{tabular} diantaranya adalah mobil, maka semakin perlu juga pengembangan sistem parkir di tempat-tempat yang padat pengunjung (mall, plaza, perkantoran) atau hunian seperti apartemen dan lain sebagainya. Di Indonesia pada umumnya sistem yang telah digunakan masih manual menggunakan tenaga manusia. Tenaga manusia diperlukan untuk menjaga didepan pintu masuk atau keluar serta di loket tempat pembayaran. Selain itu juga di dalam area parkir untuk membantu si pengemudi mobil saat memarkir mobilnya atau mencarikan posisi parkir yang kosong. Jika parkiran lebih dari satu lantai maka setiap lantai tenaga manusia dibutuhkan untuk pekerjaan yang sama. Dari pengamatan tersebut dapat dikembangkan sistem parkir yang lebih baik menggunakan teknologi elektronika.

\section{Permasalahan}

Pada penelitian ini dititikberatkan pada pengaturan parkir mulai pada saat kendaraan akan masuk area parkir, pengemudi mengetahui bagian area parkir yang masih tersedia, memudahkan pengemudi memarkir kendaraannya dan sampai pada saat kendaraan meninggalkan area parkir.

\section{Tujuan}

Tujuan tulisan ini adalah merancang dan memperbaiki sistem parkir manual/konvensional menjadi sistem yang lebih otomatis menggunakan teknologi bidang elektronika agar baik sipengemudi kendaraan maupun petugas parkir lebih mudah dalam memarkir kendaraan. 


\section{Tinjauan Teoritik}

Infrared adalah Ligth Emiting Dioda (LED) yang memancarkan cahaya infrared. LED adalah jenis semikonduktor $p$ - $n$ junction yang bekerja pada kondisi forward bias, yang dapat memancarkan radiasi dalam daerah ultraviolet, visible (sinar tampak), dan infra merah pada spektrum elektromagnetic. Radiasi cahaya yang dihasilkan LED infrared ini sebanding dengan arus forward bias yang diberikan pada LED tersebut. Led infrared berfungsi untuk memancarkan cahaya elektomagnet kasat mata.

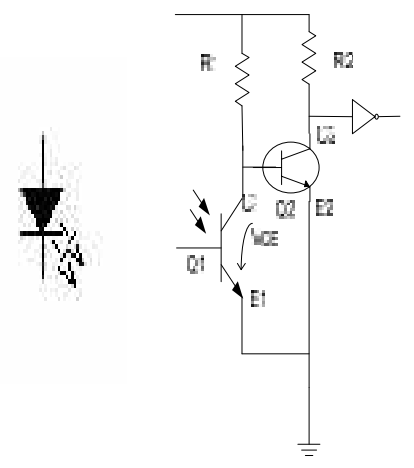

Gambar 1. Simbol infrared dan rangkaian Phototransistor

Pada gambar 1 diperlihatkan bahwa, komponen utama dari penerima infra merah adalah phototransistor, yaitu suatu alat semi konduktor cahaya yang lebih peka dari pada photo dioda p-n. Prinsip kerja phototransistor sebenarnya sama dengan transistor biasa hanya saja pada kaki basisnya sinyal yang diterima adalah berupa besaran fisik yaitu cahaya. Aktif atau tidaknya phototransistor tergantung besar atau banyaknya cahaya yang masuk ke basis

Sensor ultrasonic pada gambar 2 bekerja dengan mengirimkan gelombang suara menuju target dan mengukur waktu yang diperlukan untuk pulsa memantulkan kembali. Waktu yang diperlukan gaung untuk kembali ke sensor berbanding lurus dengan jarak atau tinggi dari objek, sebab suara mempunyai kecepatan konstan. Kecepatan gelombang bunyi tidak tergantung pada frekuensi tetapi berubah-ubah tergantung dengan jenis medianya. Kecepatan bunyi melewati zat padat kira-kira sepuluh kali lebih tinggi dari pada melalui udara (kecepatan melalui udara adalah $331 \mathrm{~m} / \mathrm{det}$ ) (sumber: Elektronika Industri hal.244). Getaran ultrasonic diproduksi dengan menggunakan resonator elektro mekanis. Pada prinsipnya sistem pemancar ultrasonic ini adalah pancaran dengan pemanfaatan getaran piezo-elektrik yang mendapatkan umpan getaran listrik dari osilator elektronik pembangkit getaran ultrasonic $40 \mathrm{KHz}$.
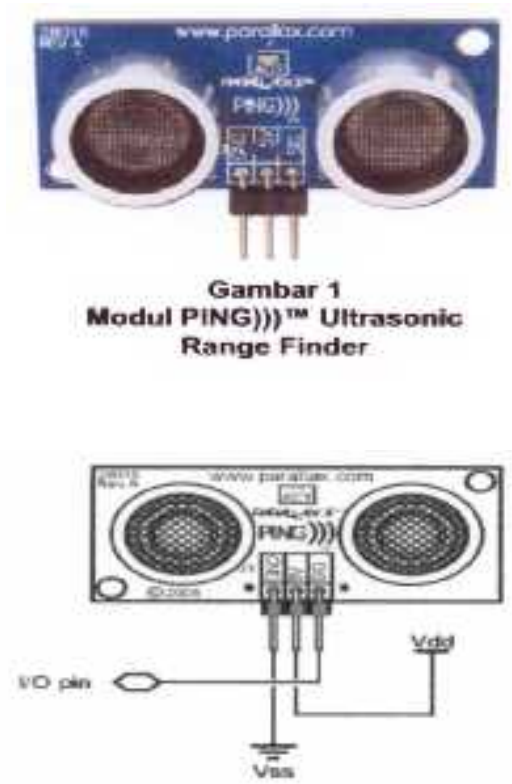

Gambar 2.sensor ultrasoic (pink)

LCD (Liquid Crystal Display) yang digunakan adalah jenis LCD yang menampilkan data dengan 2 baris tampilan pada display (lihat gambar 3). Masing-masing baris memuat 16 karakter tiap barisnya. Keuntungan dari LCD ini adalah dapat menampilkan karakter ASCII, sehingga memudahkan untuk membuat program tampilan, mudah dihubungkan dengan port $\mathrm{I} / \mathrm{O}$ karena hanya menggunakan 8 bit data 
dan 3 bit kontrol, ukuran modul yang proporsional, dan daya yang digunakan relatif sangat kecil
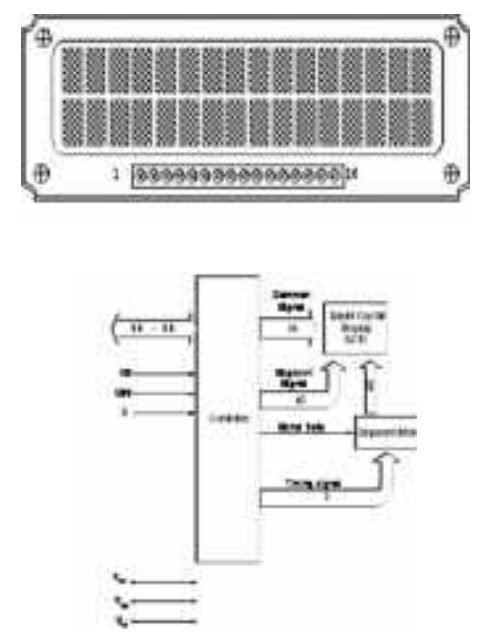

Gambar 3 . Blok Diagram LCD (Liquid Crystal Display)

Suatu mikroprosesor adalah bagian CPU (Central Processing Unit) dari sebuah komputer, tanpa memori, I/O, dan peripheral yang dibutuhkan suatu sistem lengkap. Sebagai contoh, 8088 dan 80x86 adalah suatu mikroprosesor. Untuk dapat bekerja, mikroprosesor membutuhkan perangkat pendukung yang dapat berupa RAM, ROM dan I/O. Bila sebuah mikroprosesor dikombinasikan dengan $\mathrm{I} / \mathrm{O}$ dan memori (RAM/ROM), akan dihasilkan sebuah mikrokomputer. Pada kenyataannya, mengkombinasikan CPU dengan memori dan I/O dapat juga dilakukan dalam level chip, yang menghasilkan Single Chip Microcomputer (SCM). Untuk selanjutnya, SCM dapat disebut mikrokontroler. Mikrokontroler AT89C51 pada gambar 4 dan 5, merupakan salah satu mikrokontroler keluaran dari ATMEL dengan $4 \mathrm{~K}$ byte Flash PEROM (Programmable and Erasable Read Only Memory), AT89C51 merupakan memori dengan teknologi nonvolatile memory, isi memory tersebut dapat diisi ulang ataupun dihapus berkali-kali. Mikrokontroler AT89C51 merupakan salah satu mikrokontroler keluaran dari ATMEL dengan $4 \mathrm{~K}$ byte Flash PEROM (Programmable and Erasable Read Only Memory), AT89C51 merupakan memori dengan teknologi nonvolatile memory, isi memory tersebut dapat diisi ulang ataupun dihapus berkali-kali.

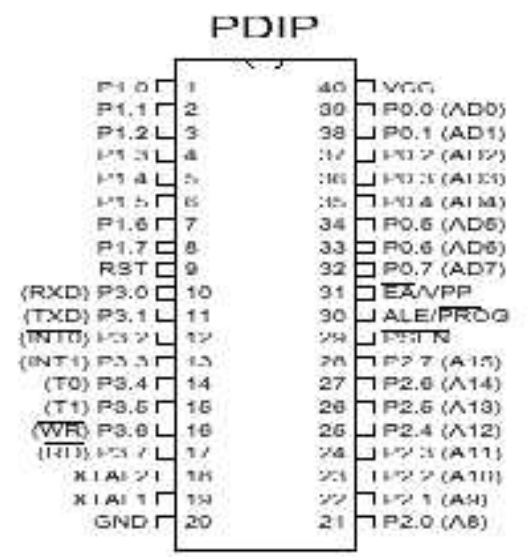

Gambar 4. Pin Mikrokontroller AT89C51

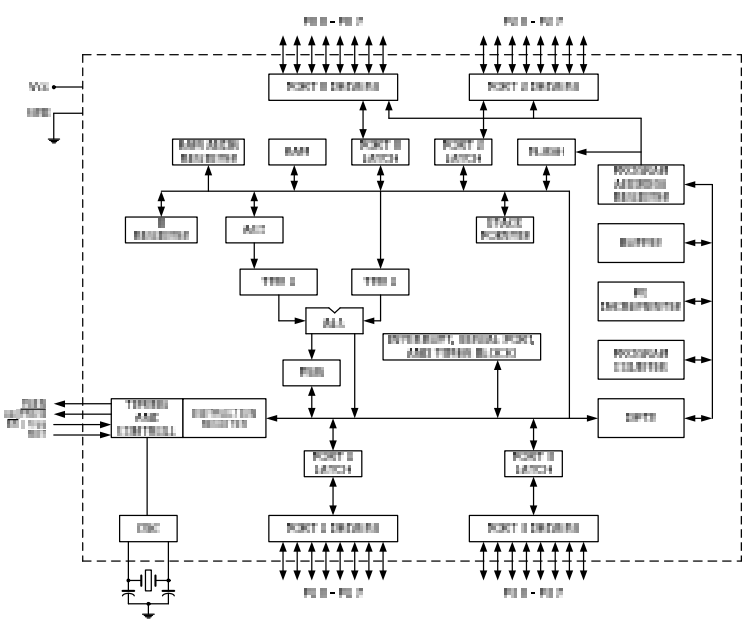

Gambar 5. Blok Diagram AT89C51

Rangkaian driver pada gambar 6 diperlukan, karena pada port input output, arus yang tersedia antara $20 \mathrm{~mA}$ sampai $40 \mathrm{~mA}$. Dengan arus yang kecil ini jika langsung dihubungkan ke masukan pada data motor stepper, maka motor tidak dapat menggerakkan rotor. Untuk menggerakkan motor, maka perlu dibuat suatu rangkaian driver atau 
rangkaian penggerak yang menghasilkan penguatan arus yang cukup besar. Pada driver rangkaian motor stepper digunakan digunakan ULN 200x, dimana pada ULN ini berisi transistor sebagai saklar (switch).

Untuk dapat menggerakkan motor stepper digunakan empat transistor penggerak, untuk menggerakkan empat buah lilitan pada motor stepper. Data input bersumber dari mikrokontroler, setiap transistor yang mendapat logika 1 akan akif. Transistor yang aktif menyebabkan terjadinya aliran arus pada lilitan, sehingga timbul medan magnet pada lilitan motor stepper. Medan magnet ini akan menggerakkan rotor motor stepper

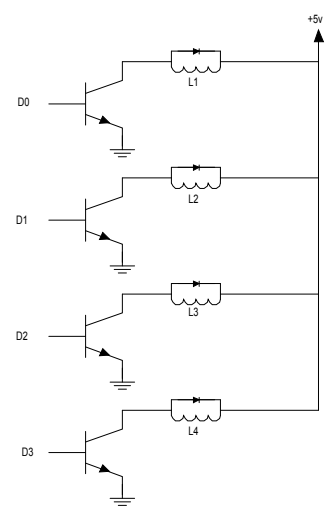

Gambar 6. Driver Penggerak Motor Stepper

Mekanisme penggerak dapat berupa motor listrik atau selinder hidrolik ataupun pneumatik. Penggerak hidrolik dan pneumatik umumnya digunakan untuk mengendalikan persendian prismatik karena penggerak ini dapat menghasilkan gerakan linier secara langsung. Oleh karena itu sering juga disebut dengan penggerak linier. Motor listrik yang menghasilkan gerakan rotasi, lebih tepat digunakan untuk mengendalikan suatu objek yang berputar. Pada penelitian ini dimanfaatkan motor stepper atau motor langkah yang merupakan suatu jenis motor listrik yang dirancang untuk digunakan dalam suatu direct digital control system. Motor stepper merupakan suatu mesin yang handal dan cocok untuk aplkasi control dan posisi, terutama jika diperlukan ketelian yang tingi. Misalnya pad a pengontrolan posisi head baca-tulis disk drive sebuah komputer dan untuk menggerakkan pena gambar sebuah $\mathrm{X}-\mathrm{Y}$ mesin plotter yang bekerja dibawah kendali sebuah komputer. Motor stepper juga banyak digunakan dalam peripheral komputer seperti sistem robotik dan aplikasi lainnya. Gerakan motor stepper dikontrol oleh sinyal digital yang akan dibangkitkan oleh suatu sistem digital. Rotor motor ini tidak berputar secara kontinyu seperti halnya motor-motor DC atau AC biasa, tetapi secara incremental dalam langkah-langkah diskrit. Secara umum setiap pulsa yang diberikan motor stepper akan membuat rotornya berputar satu langkah searah atau berlawanan arah jarum jam, tergantung kepada pola pulsa yang diberikan. Ukuran langkah ini tegantung pada desain motor stepper yang bersangkutan (biasanya bervariasi antara 0,9 derajat sampai 30 derajat). Pada alat ini motor stepper yang digunakan mempunyai sudut putar 7 derjat.

\section{METODE PENELITIAN}

Penelitian ini meliputi perangkat keras sebagai modul dan perangkat lunak sebagai pelaksana.

\section{Perancangan Perangkat Keras}

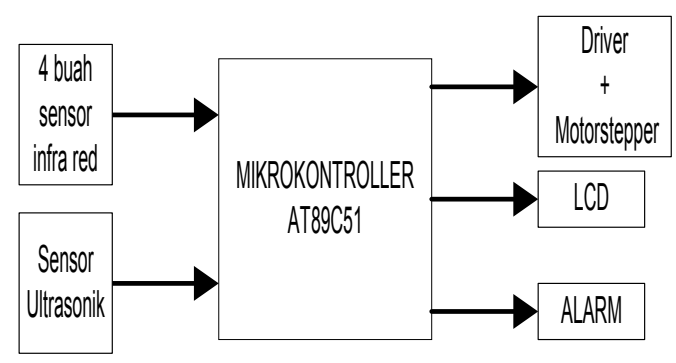

Gambar 7. Blok Diagram Sistem 
Sistem pengaman perpakiran mobil menggunakan sensor ultrasonic secara garis besar terdiri dari beberapa blok rangkaian seperti tampak pada gambar 7 yaitu: rangkaian catu daya, driver motor stepper, MC AT89C51, sensor infra merah, modul LCD, sensor ultrasonic, speaker (alarm).

Rangkaian-rangkaian elektronik yang digunakan antara lain :

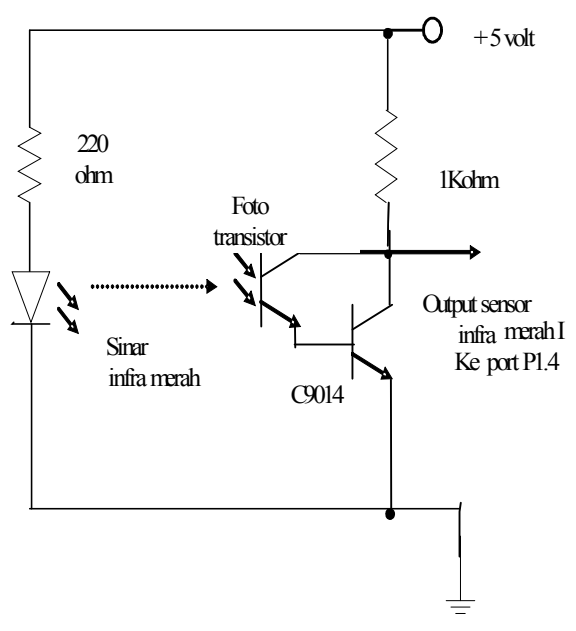

\section{Gambar 8. Rangkaian Infra red dan photo transistor}

Prinsip kerja phototransisitor sebenarnya sama dengan transisitor biasa. Hanya saja pada kaki basisinya sinyal yang diterima adalah berupa besaran fisik yaitu cahaya. Aktif tidaknya phototransisitor tergantung dari ada tidaknya cahaya yang mengenainya (lihat gambar 8).

Modul PING ini digunakan untuk mengukur jarak objek dengan cara memancarkan ultrasonic $40 \mathrm{KHz}$ selama $200 \mu$ s kemudian menungu pantulannya. Gelombang ultrasonic ini melalui udara dengan kecepatan kurang dari 344 meter per detik, mengenai objek dan memantulkan kembali ke modul PING.

Sistem minimum mikrokontroler pada gambar 9. terdiri dari IC mikrokontroler AT89C51 dan osilator dengan kristal sebagai komponen utamanya yang digunakan sebagai clock. Jalur data D0 samapai D7 dihubungkan dengan data bus sehingga pengaktifannya harus menuju alamat tertentu.

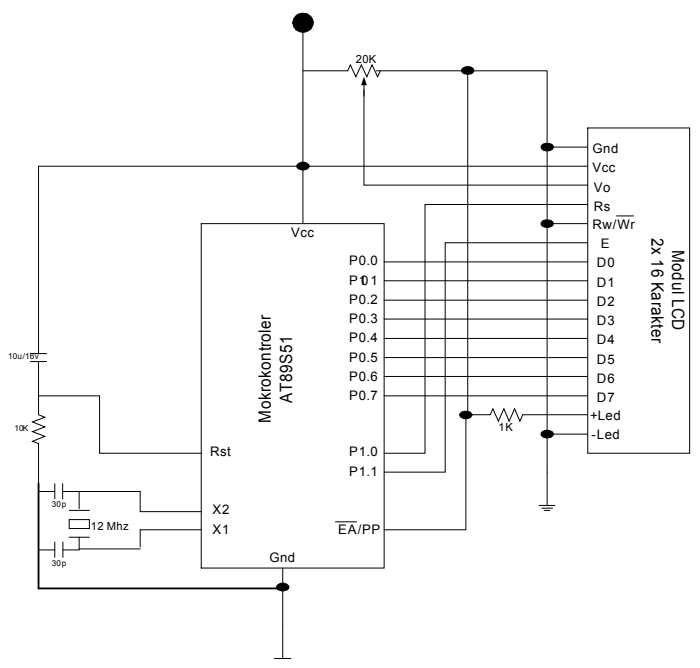

Gambar 9. Rangkaian Sistem Minimum $\& L C D$

Rangkaian penggerak motor stepper terdiri dari empat pasang transistor darlington dalam operasi saklar (switching). Tegangan yang dipakai untuk menggerakkan motor stepper sebesar 12 Volt. Dimana input rangkaiannya berasal dari mikrokontroller AT89C51 pada P2.4 sampai P2.7 untuk portal masuk. Sedangkan input untuk portal keluar yaitu P2.0 sampai P2.3. Rangkaian motor stepper dan hubungannya dengan mikrokontroler dapat dilihat pada gambar 10 berikut :

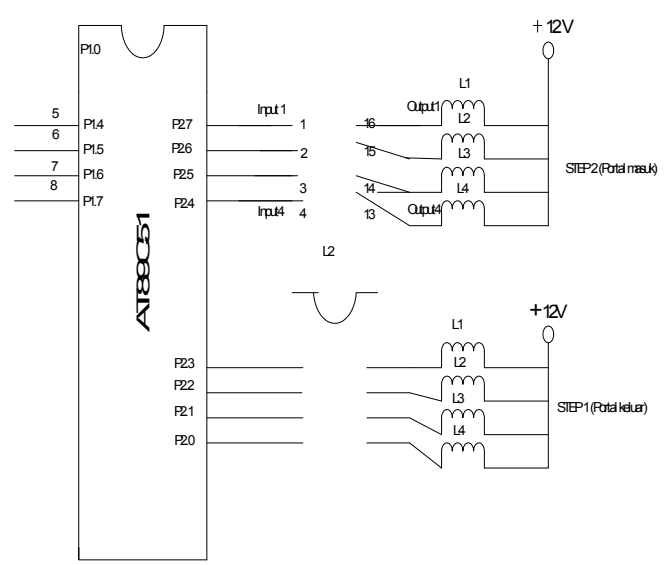

Gambar 10. Rangkaian Sistem Minimum \& Driver + Motor Stepper 
Rangkaian penguat untuk speaker berfungsi untuk mengaktifkan speaker. Input rangkaian berasal dari port 3.5 mikrokontroler AT89C51 (lihat gambar 11).

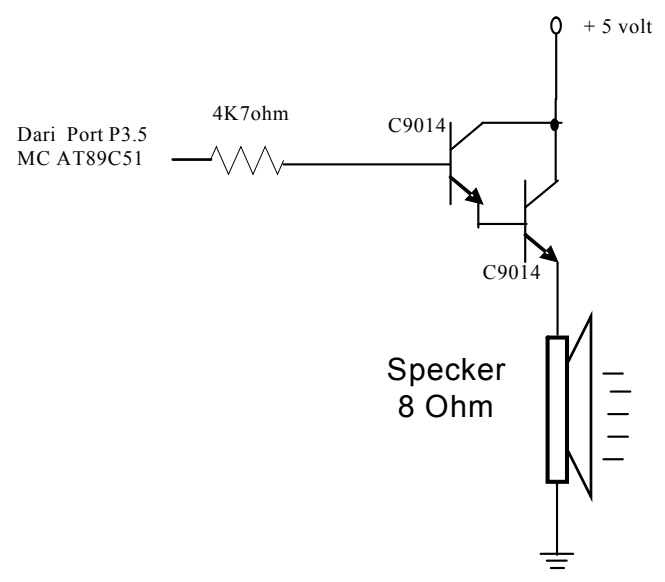

Gambar 11. Rangkaian Penguat \& Speaker

Speaker mengeluarkan suara, jika input speaker harus mendapat logika ' 0 ' dan logika ' 1 ' secara bergantian, sehingga membentuk gelombang dengan perioda dan frekuensi tertentu. Pemberian logika ' 0 ' dan logika ' 1 ' ini dapat dilakukan dari program yang ada pada mikrokontroler AT89C51.

\section{Perancangan Perangkat Lunak}

Sensor infra merah yang digunakan yaitu 4 buah. Untuk portal masuk dan portal keluar, untuk portal masuk sensor infra merah dibaca oleh program pada P1.4 dan P1.6. Maka memberikan indikasi higt dan low (I/O). Setelah P1.4 dan P1.6 diaktifkan kemudian data input akan dilanjutkan pada pengaktifan data pada P2.4 - P2.7 sebagai penggerak motor stepper portal gerbang masuk . Indikasi ini menjadi input pada tampilan LCD untuk menghitung jumlah kendaraan masuk.

Untuk portal keluar sensor infra red dibaca pada P1.5 dan P1.7 juga memberikan indikasi high dan low(I/O).
Setelah diaktifkan P1.5 dan P1.7 diaktifkan kemudian data pada P2.0 P2.3 sebagai penggerak motor stepper pada portal gerbang keluar, indikasi ini menjadi input pada tampilan LCD untuk menghitung jumlah mobil keluar. Selain menggunakan sensor infra red sebagai portal masuk dan portal keluar juga menggunakan sensor ultrasonic Sistem kerja peralatan sebagai berikut sinyal ultrasonik yang dipancarkan dikirimkan melalui pemancar ultrasonik, kemudian mengenai penghalang berupa dinding mobil. Gelombang yang dipancarkan akan dipantulkan kembali dan ditangkap oleh penerima sensor ultrasonic. Pemancaran akan gelombang akan diteruskan ke MC AT89C51 dan kemudian diproses. Pada jarak tertentu MC AT89C51 akan memberikan informasi bahwa jarak antara mobil dan halangan pada jarak yang dekat, maka alarm akan berbunyi.

\section{Pengujian Sistem}

Ada beberapa metode yang dapat digunakan dalam melakukan pengujian sistem kelistrikan, antara lain:

1. Pengujian tanpa tegangan dari catu daya

Pengujian cara ini mencakup pengujian sambungan-sambungan kaki komponen dan keberadaan jalur. Pengujian ini bertujuan untuk meminimalkan kesalahan sehingga kerusakan koponen dapat dihindari.

2. Pengujian saat operasi minimal

Pengujian ini bertujuan untuk mengetahui besarnya penyimpangan antara hasil perhitungan dengan angka hasil pengukuran. Persentase kesalahan dapat ditentukan dari perbandingan antara perhitungan dengan hasil pengukuran. Hal ini bertujuan untuk mengetahui apakah operasi tetap normal selama pengujian

Data Pengukuran I/O mikrokontroler

1. Tegangan input - Saat sensor tidak aktif : 4,7 Volt 
- Saat sensor aktif : 0,32 Volt

2. Tegangan Output

- Saat berlogika 0 : 0 Volt

- Saat berlogika 1: $4 \mathrm{Vol}$

Data Pengukuran Rangkaian Driver

1. Tegangan supply: 12 Volt

2. Tegangan input : 2,8 Volt dan 4 Volt

3. Tegangan output : 11,2 Volt

Pengujian software bertujuan untuk melihat apakah program yang dibuat bekerja dengan baik sesuai dengan yang dinginkan. Pengujian yang dilakukan adalah terhadap input/output mikrokontroler.

Pengujian terhadap input mikrokontroler yang dihubungkan dengan sensor infra red + phototransistor terhadap output yang terhubung ke driver + motor stepper untuk buka/tutup portal dan output untuk tampilan pada LCD jumlah kendaraan di area parkir. Pengujian untuk input sensor ultrasonic PING terhadap output alarm.

\section{HASIL DAN PEMBAHASAN Hasil}

Modul dan alat yang dibuat dapat digunakan untuk mengatur kendaraan yang masuk ke area parkir. Saat kendaraan akan masuk portal akan terbuka otomatis jika area parkir masih tersedia dan LCD menampilkan banyak kendaraan yang berada di area parkir. Saat pengendara akan menempatkan kendaraan di parkir maka alarm akan berbunyi saat kendaraan pada posisi tidak aman terhadap pembatas dan sebaliknya jika posisi aman alarm tidak berbunyi. Ketika kendaraan keluar area, portal akan terbuka otomatis dan banyak kendaraan akan berkurang pada tampilan LCD.

\section{Pembahasan}

Pada saat sinar infra merah yang dipancarkan LED infra merah tidak terhalang menuju fototransistor, basis fototransistor mendapat bias tegangan dari cahaya tersebut, akibatnya tegangan pada basis fototransistor menjadi naik. Hal ini menyebabkan fototransistor menghantar sampai ke daerah jenuh, sehingga tegangan antara kolektor dan emitor fototransistor terdapat tegangan lebih kurang 0,1 volt $(\mathrm{VCE}=0,1$ volt). Ini berarti output dari rangkaian berlogika '0'. Sebaliknya pada saat sinar infra merah yang dipancarkan LED infra merah terhalang menuju fototransistor, basis fototransistor tidak mendapat bias tegangan dari cahaya tersebut, akibatnya tegangan pada basis fototransistor menjadi 0 volt. Hal ini menyebabkan fototransistor dalam kondisi cut off (menyumbat), sehingga tegangan antara kolektor dan emitor fototransistor terdapat tegangan yang

sama dengan VCC yaitu lebih kurang 4,9 volt $(\mathrm{VCE}=4,9$ volt $)$. Hal ini berarti output dari rangkaian berlogika ' 1 '.

Sensor ultrasonik merupakan sensor yang bekerja berdasarkan prinsip pantulan gelombang suara yang dipancarkan akan ditangkap kembali dengan perbedaan waktu sebagai dasar penghindaranya. Sehingga dengan demikian, pada saat mobil akan parkir pada jarak tertentu dengan dinding atau penghalang pengemudi bisa menghentikan mobilnya. Frekuensi yang digunakan adalah $20 \mathrm{KHz}$, diameter sensor dalah $16 \mathrm{~mm}$, tinggi dari sensor $12 \mathrm{~mm}$ dan jarak maksimum pendeteksinya yang didapat pada pengukuran adalah $5 \mathrm{~m}$. Pada sistem perparkiran ini jarak yang dapat dideteksi $\pm 40 \mathrm{~cm}$. Gelombang akan dipancararkan oleh rangkaian transmiter yang inputnya berasal dari P3.3 mikroprocessor kemudian ditangkap oleh halangan. Setelah pancaraan gelombang ditangkap maka akan dipantulkan kembali sehingga diterima oleh rangkaian receiver. Kemudian menggerakan relay. Setelah relay dalam keadaan close atau terhubung maka speker akan berbunyi. 
Setelah program didownload dan dijalankan pada maniatur sistem menggunakan sensor ultrasonic ini program akan memberikan kerja sistem secara sekuensial (urut) sebagai berikut: Sensor infra merah yang digunakan yaitu 4 buah. Untuk portal masuk dan portal keluar, untuk portal masuk sensor infra merah dibaca oleh program pada P1.4 dan P1.6. Maka memberikan indikasi higt dan low (I/O). Setelah P1.4 dan P1.6 diaktifkan kemudian data input akan dilanjutkan pada pengaktifan data pada P2.4 - P2.7 sebagai penggerak motor stepper portal gerbang masuk . Indikasi ini menjadi input pada tampilan LCD untuk menghitung jumlah kendaraan masuk. Untuk portal keluar sensor infra red dibaca pada P1.5 dan P1.7 juga memberikan indikasi high dan low(I/O). $\begin{array}{llll}\text { Setelah diaktifkan } & \text { P1.5 dan } & \text { P1.7 }\end{array}$ diaktifkan kemudian data pada P2.0 P2.3 sebagai penggerak motor stepper pada portal gerbang keluar, indikasi ini menjadi input pada tampilan LCD untuk menghitung jumlah mobil keluar. Sealain menggunakan sensor infra red sebagai portal masuk dan portal keluar juga menggunakan sensor ultrasonic Sistem kerja peralatan sebagai berikut sinyal ultrasonik yang dipancarkan dikirimkan melalui pemancar ultrasonik, kemudian mengenai penghalang berupa dinding mobil. Gelombang yang dipancarkan akan dipantulkan kembali dan ditangkap oleh penerima sensor ultrasonic. Pemancaran akan gelombang akan diteruskan ke MC AT89C51 dan kemudian diproses. Pada jarak tertentu MC AT89C51 akan memberikan informasi bahwa jarak antara mobil dan halangan pada jarak yang dekat, maka alarm akan berbunyi.

\section{KESIMPULAN DAN SARAN}

Dari penelitian ini dapat

disimpulkan, antara lain :

1. Modul pengaturan parkir kendaraan masuk/keluar area parkir dan membantu pengemudi saat parkir, secara otomatis akan membuka atau menutup portal, baik ketika kendaraan masuk/keluar area parkir.

2. Modul pengaturan parkir kendaraan masuk/keluar area parkir dan membantu pengemudi saat parkir, secara otomatis juga akan membantu pengemudi saat menempatkan kendaraan pada posisi aman di area parkir.

Pada tulisan ini disarankan antara lain : pada sistem parkir ini sebaiknya untuk keamanan ditambah dengan menggunakan sistem pendeteksi plat kendaraan mobil supaya tidak adanya kejadian kehilangan kendaraan, kartu tanda masuk yang dapat menentukan jumlah biaya parkir dan nomor plat kendaraan serta lamanya kendaraan berada di area parkir tersebut.

\section{DAFTAR PUSTAKA}

Putra, Agfianto Eko, 2002, Belajar Mikrokontroller AT89C51. Gava Media, Yogyakarta.

Suhata ST., 2004, Aplilkasi Mikrokontroller Sebagai Pengendali Peralatan Elektronik Via Line Telepon. Elex Media

Komputindo, Jakarta

http://www.tokoelektronika.com/tutorial/ paralel.html

http://www.doc.ic.ac.uk/ ih/doc/stepper/ control2/connect.html

http://www.atmel.com

http://www.batronix.com

http://www.google.com 
ISSN : 2085-6989 